\title{
Application of flat belts in advanced machine constructions
}

\author{
Zastosowanie pasów płaskich \\ w zaawansowanych konstrukcjach maszyn
}

GRZEGORZ DOMEK
MICHAŁ WILCZYŃSKI
TADEUSZ WOŹNIAK*
The paper presents some issues of flat belts use in advanced machine designs. These belts allow realizing for the most complex drive and conveyor solutions as well as complex functions. They work in the drives at the highest speed, carry the highest torque, work with wheels arranged in various planes. With the use of modern material for belts, it is possible to obtain gearboxes with a wide range of applications, which should make them the most popular in machine construction.

KEYWORDS: flat belts, belt drives

Basic barriers to the use of flat belts in production systems are mostly ignorance and prejudice. Belts are often part of the machine, which simultaneously functions as a gearbox and coupler. Mark Twain once said: The reports of my death have been greatly exaggerated. To paraphrase this statement, one can say: flat belts are too outdated for advanced machine construction. Nevertheless, the most difficult drive and conveyor problems can still be solved using them.

Flat belt drives were one of the first towing gears and, after the introduction of other types of torque drive belts, their role was limited to conveyor belts (fig. 1). They were called transport and process belts, which was not a very successful translation from German, suggesting that their function was very simple (moving a product from $A$ to $B$ or being a part of a production process). In recent years, functions and quality of belts have evolved considerably - construction has been made, which can meet the highest demands of modern machines [3]. On some drives, flat belts reach the highest speeds that are not available for other belt types. They are also used in presses, where wooden boards or plastics are pressed under high pressure. Highest torque drives also use flat belts [2].

\footnotetext{
* Dr hab. inż. Grzegorz Domek (gdomek@ukw.edu.pl), prof. UKW; dr hab. inż. Tadeusz Woźniak, prof. UKW (wozniak@ukw.edu.pl) Instytut Techniki, Uniwersytet Kazimierza Wielkiego; mgr inż. Michał Wilczyński (mwilczynski@whm.pl) - WHM Polska Sp. z o.o.
}

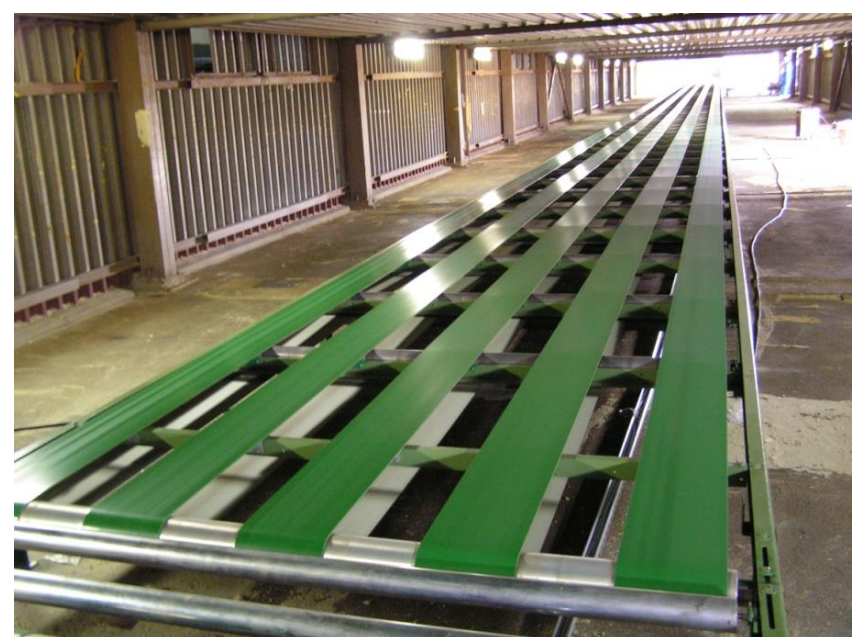

Fig. 1. Conveyor belt system in a PU foam factory

\section{Problems with flat belts operation}

The main feature of the belt drives is the transfer of torque over a long distances, although they can also perform the functions of other transmission, cylinders and drive shafts. The belts are used, because they are lightweight and make the drive do not emit excessive noise. "Heavier" solutions cause energy losses, but the users find them more durable. This is wrong thinking the problem of durability solves the choice of the right material, also for other drives.

Durability of conveyor and propulsion belts systems is dependent on a volume and energy consumption. Belts are mostly made up of synthetic and natural polymers, in which the energy consumption of the bonds between the polymer chains leads to weakening of the material structure and cracking. The belts are also made of crystalline materials (e.g. steel belts) - in this case, the material can be fatigued after some time [1]. Volumetric wear is mainly related to the abrasion, although there is also a crushing of the material. Polymer belts are crushed in the first cycle and, of course, after a long period of time - due to material creeping. Abrasion refers to all drive and conveyor belts; it is the result of friction or 
friction-shaped belt coupling [5]. In the real belt drive, the belt slippage is related to the compensation of the active cable extension relative to the passive rod. Since gliding occurs in each belt drive, the abrasion occurs at each as well.

The belts and pulley wheels are selected so that the friction pair (belt - wheel) ensures the highest efficiency of the transmission - only abrasion is designed in the next order. First, the wheels very resistant to abrasion are selected, and then the belt made of abrasionresistant material, but the priority is the coefficient of friction. Constructors often think that the coefficient of friction is directly proportional to the abrasion. Unfortunately, it is not. Similarly, the hardness of the belt and the pulley wheel does not translate directly into the abrasion resistance, which is related to the internal structure of the material (fig. 2) [4].

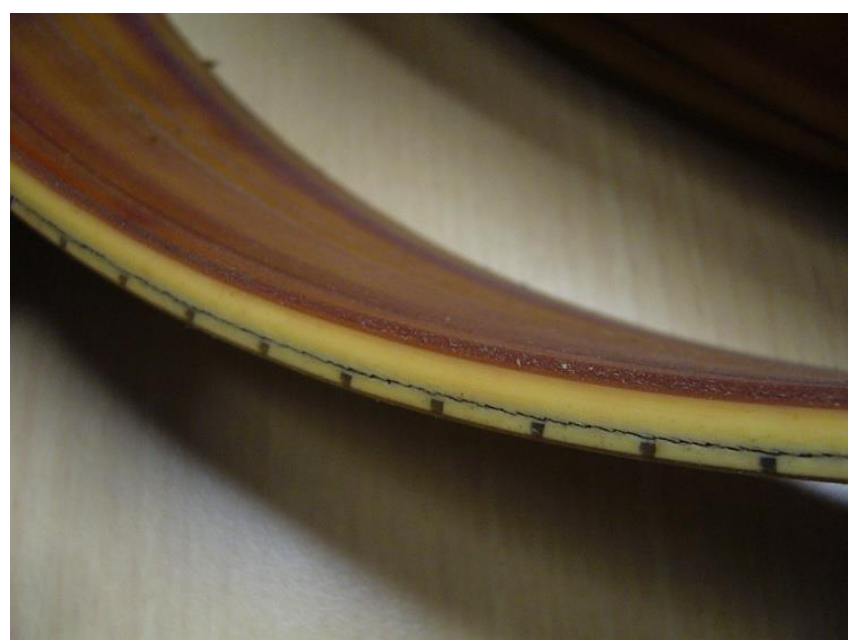

Fig. 2. Flat belt used in the processing of floor panels

The first flat belts were made of leather, but later, this material was considered not very durable and was replaced by others. Today, many of the belts built on modern warp are covered with leather, because it is very resistant to abrasion and high temperatures. Occurrence of the permanent slip on wheels does not damage the belt, and after reducing the peripheral force, the belt may continue to work [10]. Leather belts are suitable for working under the harshest conditions (e.g. as a chipper in a wood panel manufacturing plant). Material abrasion is a special feature when it comes to tire selection: rubber - for motor vehicles, polyurethane - for industrial vehicles, steel - for rail vehicles. It is similar to belts working in difficult conditions. Depending on them, different types are selected:

- rubber - for belts working outdoors,

- polymers - for belts working in closed facilities,

- steel - for belts subjected to extreme pressure and working in very difficult conditions.

Conditions associated with belt work are often very complex. The belts issuing banknotes at ATMs cannot fail, although the parameters of the environment during the year change diametrically. Likewise, belts working in an explosive or chemically aggressive environment. Material of the belt in the cigarette production systems penetrates the tobacco and is burned together with it, so the range of materials used there is very limited [7]. Conveyor belts in sugar production are heavily abraded after two years of operation, half of the belt is worn. The abrasive product - hundreds of kilograms of plastic - goes to sugar. The material of the belt must therefore be allowed to come into contact with food, and for several years, the European standards have regulated the amount of material that can migrate from the food belt.

\section{Coupling the belt with the pulley wheel}

Euler described the friction of a thread with a wheel in his works, and although this problem was later evoked by many authors, development of the Euler formula allows for understanding the phenomena occurring in the flat belt drive. In the real gearbox, processes that take place between the belt and the pulley wheel and between the belt material and the cord, should be indicated. Modern types of fibers used in the belt have improved mechanical properties. The ratio of elongation of the active to passive cable is approaching unity. Quality of the coupling depends on the friction coefficient of the belt to the pulley wheel $\mu_{z}$ and the friction inside the belt $\mu_{w}$. The coupling in the drive can be described as follows:

$$
\frac{\mathrm{d} S_{1}}{\mathrm{~d} S_{2}}=\mathrm{e}^{\beta \mu}
$$

where: $\mu$ - coefficient of friction $\left(\mu=\mu_{z}+\mu_{w}\right) ; \beta$ - pulley wheel circumference expressed in radians; $S_{1}-$ tension in active band, $S_{2}$ - tension in passive band, $e-$ base of natural logarithm.

Tensile strength of the belt improves the running conditions of the tread surface. It is not stretched and does not cause fatigue. The problem of modern belts is the rheological phenomena, coherence of the cord with the belt material and linear speed of the belt. If the ratio of elongation of the active band $\Delta L_{c}$ to the passive band $\Delta L_{b}$ tends to unity, deformation of the material below the support layer, consisting of compression and horizontal displacement with respect to the cord, should be considered. So if:

$$
\frac{\Delta L_{\mathrm{c}}}{\Delta L_{\mathrm{b}}} \gg 1
$$

then coupling in a flat belt drive is a function of the belt material $\sigma$, contact surface with the pulley wheel $D$, peripheral force $F_{o}$, pre-stressing force $F_{r}$ and the height of the belt layer $h$ below the carrier layer:

$$
\frac{d S_{1}}{d S_{2}}=f\left(\sigma, h, D, F_{r}, F_{o}\right)
$$

\section{Running the belt on pulley wheels}

Moving the flat belt around the pulley wheel seems to be one of the major problems that have caused these drives to quit. This problem was solved many years ago and nowadays, flat belts are best suited to driving wheels in different planes (fig. 3). The pulleys, and at least the propulsors, should be of a barrel shape. It is possible to place a wedge profiles with a correspondingly shaped wheel on the running side, and in many cases a mechatronic belt adjustment system are applied. They neutralize the effect of changing the force acting on the belt at its width and the mounting and structural errors of the mechanical systems. The inadequacies of the machines, in which the belt drives are mounted, also cause damage to other types of belts $[5,6]$. 


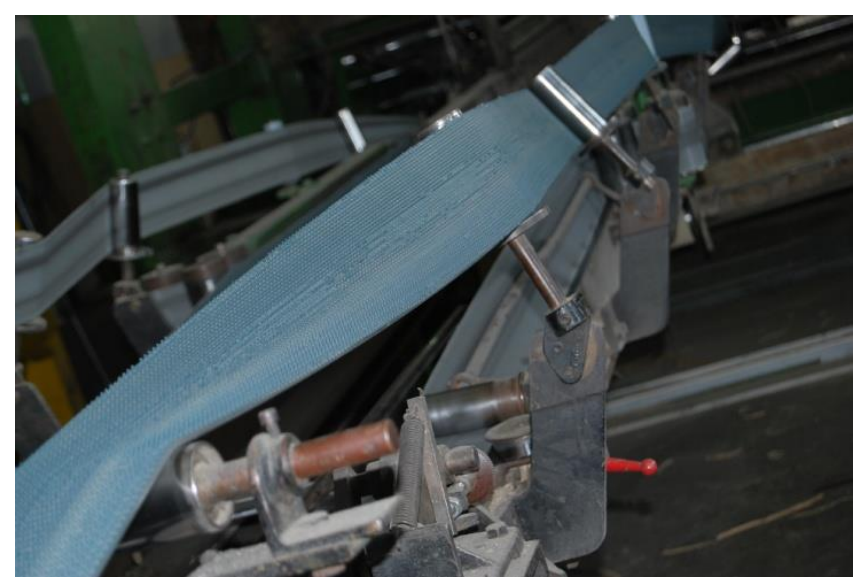

Fig. 3. Belt system in a paper packaging plant

\section{Selection of drive drum diameter and belt bending problem}

For many years, in the selection of parameters of belt drive elements, designers have been helped with the computational programs provided by belt manufacturers [9]. There are a number of constraints and fixed sizes in these programs, and the results do not overlap with the calculations performed on their own. The software excludes extreme results (e.g. too narrow belt, too small pulley wheel diameter) and additionally it contains a number of parameters that determine the properties of the belt. Placing these parameters in the compiled program protects the manufacturer against the dissemination of this knowledge. Sometimes, the best way to choose a belt is to select the minimum diameter of the wheel, on which the belt can work. This is the way to choose the most powerful belt - it is probably oversized, but it will certainly do its job well and will not break on pulley wheels.

\section{Conclusions}

In modern flat belts, the support layer is made of materials that provide as little elongation as possible and at the same time retaining elasticity on small diameter pulley wheels. Carbon fiber and steel (top quality) ensure the stability of the flat belt support. Nowadays, wheel coupling depends to a large extent on the material used on the active side.

Although it was possible to obtain (as in the assumptions for the Euler equation) an almost unstretchable cord, the problem of the band mass and its thickness still remained. Therefore, on the running side of the belt, materials with a high coefficient of friction for the wheel material, non-deformable and lightweight, are used, the layer being made as thin as possible. It should be assumed that the thinner the running layer, the higher the efficiency of the belt drive. In recent years, many new flat belt designs have been designed, and development of material engineering has allowed to expect another modern belts and successes in their applications.

\section{REFERENCES}

1. Alipour A., Naderi G., Bakhshandeh G.R., Vali H., Shokoohi S. "Elastomer nanocomposites based on NR/EPDM/ Organoclay: morphology and properties". International Polymer Processing. XXVI, 1 (2011).
2. Dressing H., Holzweissig F. "Dynamics of Machinery, Theory and Applications". Berlin Heidelberg: Springer Verlag, 2010.

3. Domek G., Dudziak M. "Algorythm for choosing the gears with timing belts". Machine Dynamics Problems. 30, 3 (2006): pp. $65-67$.

4. Domek G., Kołodziej A. "The surface conditions of pulleys in use". Machine Dynamics Problems. 30, 3 (2006): pp. 72-78.

5. Domek G., Krawiec P. "Methods of designing of timing belts pulley". University Reviev. 1, 3 (2007): pp. 15-20.

6. Domek G., Kołodziej A. „Problem porządkowania produktów spożywczych na przenośnikach pasowych". Inżynieria $i$ Aparatura Chemiczna. 1 (2007): pp. 42-43.

7. Domek G. „Studium projektowania cech konstrukcyjnych i eksploatacyjnych pasów zębatych". Wydawnictwo Uniwersytetu Kazimierza Wielkiego, 2013.

8. Dudziak M. „O problemach tarcia wewnętrznego i dyssypacji energii w gumowych pasach cięgnowych". Poznań: Wydawnictwo Politechniki Poznańskiej, 1990.

9. Dudziak M., Domek G. „Podstawowe moduły programu obliczeniowego przekładni pasowych". XVI Konferencja „Metody i środki projektowania wspomaganego komputerowo"COSIM'07. Politechnika Warszawska, Nałęczów 10 12.10.2007, pp. 33-34.

10. Schafer F.H. „Antriebsriemen“. Höxter (Germany): Huxaria Druckerei, 2008. 